University of Nebraska - Lincoln

DigitalCommons@University of Nebraska - Lincoln

Faculty Publications from the Harold W. Manter Laboratory of Parasitology

10-1-1992

\title{
A New Species of Linstowia (Cestoda: Anoplocephalidae) from Marsupials in Bolivia
}

\author{
Scott Lyell Gardner \\ University of Nebraska - Lincoln, slg@unl.edu \\ Mariel L. Campbell \\ University of New Mexico, campbell@sevilleta.unm.edu
}

Follow this and additional works at: https://digitalcommons.unl.edu/parasitologyfacpubs

Part of the Parasitology Commons

Gardner, Scott Lyell and Campbell, Mariel L., "A New Species of Linstowia (Cestoda: Anoplocephalidae) from Marsupials in Bolivia" (1992). Faculty Publications from the Harold W. Manter Laboratory of Parasitology. 23.

https://digitalcommons.unl.edu/parasitologyfacpubs/23

This Article is brought to you for free and open access by the Parasitology, Harold W. Manter Laboratory of at DigitalCommons@University of Nebraska - Lincoln. It has been accepted for inclusion in Faculty Publications from the Harold W. Manter Laboratory of Parasitology by an authorized administrator of DigitalCommons@University of Nebraska - Lincoln. 


\title{
A NEW SPECIES OF LINSTOWIA (CESTODA: ANOPLOCEPHALIDAE) FROM MARSUPIALS IN BOLIVIA
}

\author{
Scott L. Gardner and Mariel L. Campbell \\ Department of Nematology, The University of California, Davis, California 95616-8668
}

ABSTRACT: A new species of cestode of the genus Linstowia (Cestoda: Anoplocephalidae) is described from marsupials of the genera Thylamys and Monodelphis. The new species (Linstowia schmidti) differs from Linstowia iheringi Zschokke, 1904, in having a much smaller strobila and reduced number of proglottids, and in the distribution of the eggs in gravid proglottids. In Bolivia, cestodes of the genus Linstowia appear to have a restricted geographic distribution, occurring in marsupials only in southeastern Bolivia near the western margin of the Chaco. This host-parasite association may represent an ecological-historical relict.

Cestodes of the genus Linstowia Zschokke, 1899, parasitic in didelphid marsupials in South America, have been little studied since the first works of Zschokke (1899, 1904a, 1904b) when the taxonomy and geographic distribution of these cestodes first were described. These cestodes occur in South American didelphid marsupials and Australian marsupials and monotremes (Zschokke, 1899, 1904a, 1904b; Janicki, 1906; Gomes, 1979; Beveridge, 1983). Up to the present time, 3 species of Linstowia have been reported from Australia, whereas only a single species, Linstowia iheringi Zschokke, 1904, has been described from marsupials in the neotropics. Since the first description of $L$. iheringi based on specimens collected in Brazil by von Ihering, only Gomes (1979) has reported these cestodes from South American marsupials, also from Brazil. At present, very little is known of the abundance, diversity, and geographic distribution of these cestodes in South American marsupials.

Equally little is known of the helminth fauna of marsupials of the genera Thylamys and Monodelphis in the neotropics, and prior to our work in Bolivia almost no information was available concerning the ecological relationships of marsupials and their parasites in that biotically diverse country. In collaboration with individuals from the Zoo Santa Cruz, Fauna Sudamericana, the National Museum of Natural History, La $\mathrm{Paz}$, the American Museum of Natural History, and the Museum of Southwestern Biology, we were able to analyze data on the endoparasites from a large series of marsupials collected from throughout Bolivia. In the present paper we describe a new species of Linstowia from species

Received 31 May 1991; revised 18 November 1991; accepted 21 November 1991. representing the didelphid genera Thylamys and Monodelphis collected in Bolivia.

We follow Schmidt (1986) in recognizing the Linstowiinae as a subfamily of Anoplocephalidae. Beveridge (1983) followed Baer (1927) in using 2 subgenera (Paralinstowia Baer, 1927, and Linstowia) for species of Linstowia. We consider the cestodes discussed in the present paper to represent a species of the genus Linstowia because of the presence of egg capsules (1 capsule around each egg) in the gravid proglottids and the fact that the terminal genital canals pass ventrally to the excretory canals. The new species is assigned to the subgenus Paralinstowia in that it has a small cirrus pouch and relatively few testes (Beveridge, 1983).

\section{MATERIALS AND METHODS}

Cestodes were obtained from marsupials from a single locality in the department of Chuquisaca, Bolivia, from 6 to 15 July 1985 . The collection locality, in the vicinity of Porvenir, is a deciduous tropical woodland in the Andean foothills near the western margin of the Chaco thorn forest (Unzueta, 1975). Marsupials were collected in live-traps and examined for helminth parasites within a few minutes of death in most cases.

Cestodes were collected from the small intestine, killed, and relaxed in distilled water and preserved in $10 \%$ formalin. Specimens were stained in either Grenacher's carmine or Ehrlich's hematoxylin, dehydrated in ethanol, cleared in terpineol and xylene, and permanently mounted on a slide in Canada balsam. All measurements are given in micrometers with means following in parentheses unless otherwise indicated.

\section{DESCRIPTION \\ Linstowia schmidti n. sp. (Figs. 1-5)}

Diagnosis: Total length $(\mathrm{n}=7) 7.17-12.20 \mathrm{~mm}$ (9.64 mm); maximum width $(\mathrm{n}=8)$ 690-1,010 (830), attained in late mature proglottids. Strobila consists of 24-38 (29) craspedote proglottids. Mature proglottids wider than long (about half as long as wide), with lengthto-width ratio of $0.43-0.49(n=3)$ in last mature proglottid. Increase in relative length beginning in proxi- 


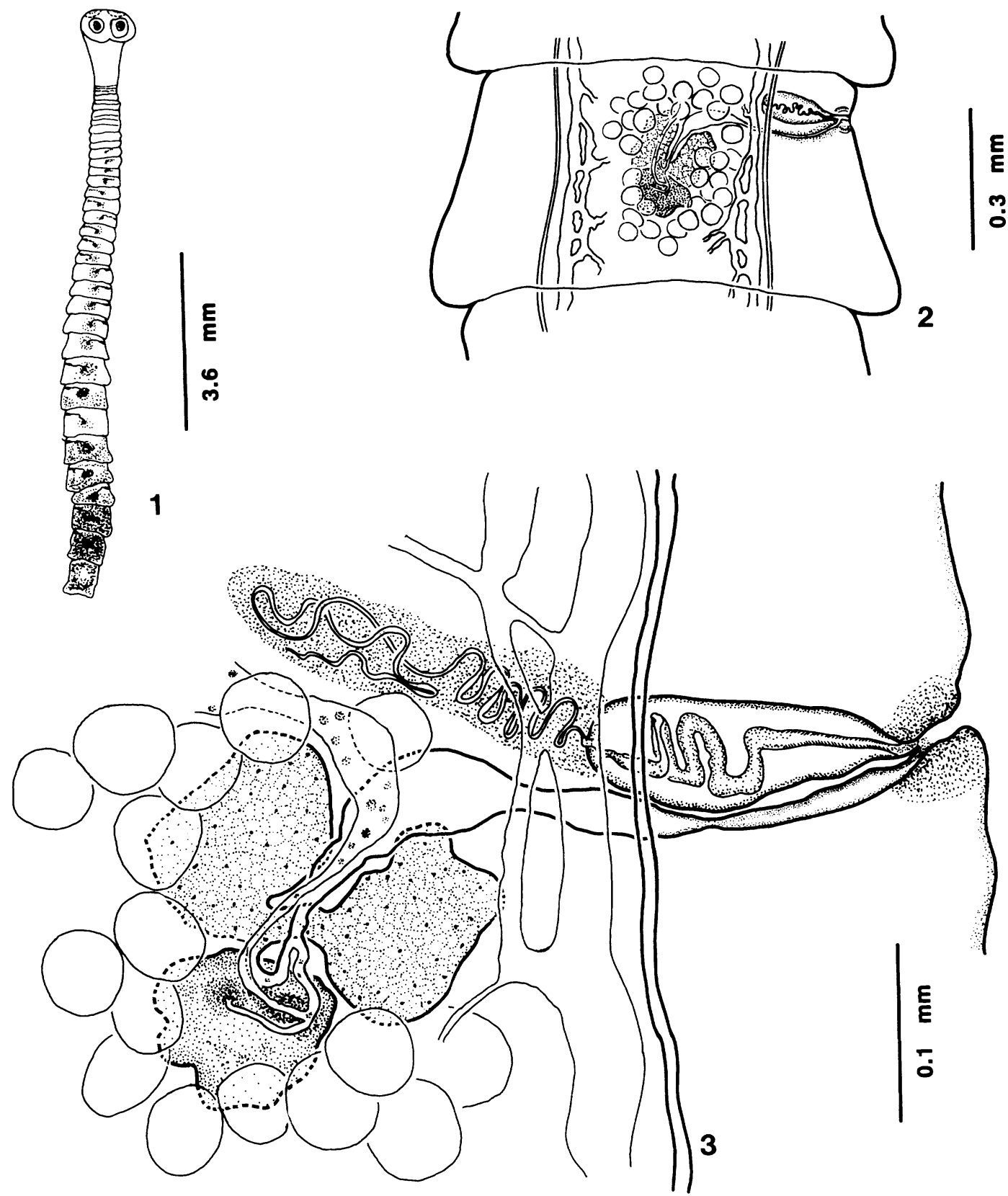

FIGURES 1-3. Characteristics of Linstowia schmidti n. sp. from Bolivian marsupials. 1. Strobila and scolex showing characteristic elongation of terminal gravid proglottids. 2. Dorsal view of mature proglottid. 3. Enlarged view of mature proglottid, dorsal view.

mal gravid proglottids results in tapering toward the last proglottid, which is always longer than wide. Scolex 496-845 (690) long by 745-1,042 (891) wide. Suckers 294-407 (350) × 298-414 (351). Genital pores irregularly alternating. Genital atrium with delicate musculature, opening on anterior lateral margin of proglottid. Genital ducts pass ventrally to paired longitudinal osmoregulatory canals. Dorsal excretory canal 4-10 in diameter, external to ventral canal. Ventral canal fenestrated, 18-60 in diameter, connecting with ventral canal in the opposite side of the proglottid by anastomosing branches. Cirrus sac ovoid, 83-160 (130) $\times$ 55-71 (64), extending to level of ventral osmoregulatory canal. Cirrus spinose, coiled within cir- 

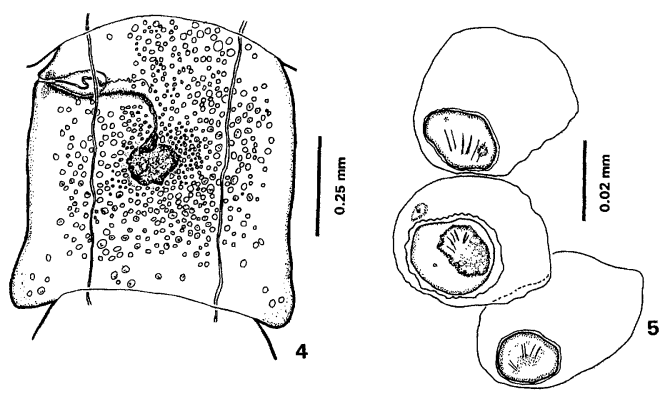

Figures 4, 5. Characteristics of gravid proglottids of Linstowia schmidti $\mathrm{n}$. sp. from Bolivian marsupials. 4. Dorsal view of penultimate gravid proglottid showing distribution of eggs through proglottid. 5. Detail of eggs, indistinct egg shell, and egg capsule from ultimate gravid proglottid. Eggs illustrated were located in uncrowded marginal region of proglottid.

rus sac. Vas deferens coiled, surrounded by glandular cells, anterior to ovary. Internal and external seminal vesicles absent. Testes subspherical, 25-38 (29) per proglottid, distributed dorsally across medulla between osmoregulatory canals, frequently overlapping reproductive structures. Testis diameter 30-49 (40). Vagina surrounded by glandular cells, vaginal canal forming expanded seminal receptacle dorsal and anterior to ovary when filled with sperm. Seminal receptacle variable, 77-130 (100) × 17-45 (32). Duct from seminal receptable narrow, proceeding posteriad from seminal receptacle joining with oviduct and forming the fertilization canal. Dorsal to vitelline gland, short vitelline canal fuses with fertilization duct, which subsequently loops anterodorsally before entering Mehlis's gland. Ovary bilobed with narrow central isthmus 100-161 (122) in maximum length by 115-183 (154) in maximum width. Vitelline gland 59-86 (69) in maximum length by $60-95$ (75) in maximum width, situated ventral and posterior to ovary. Uterine duct passes anteriorly and dorsally from Mehlis's gland, then descends to enter the uterus anteroventrally to the ovary. Uterus ventral to ovary, never distinct, transforming into egg capsules in gravid proglottid. On transformation of uterus, eggs disperse throughout parenchyma with relatively more ripe eggs in outer margins of proglottids (Fig. 4). Eggs ovoid (Fig. 5), hexacanth embryo 23-27 $(25) \times 15-27(21)$. Egg capsules indistinct, visible in margins of proglottids.

\section{Taxonomic summary}

Type host: Thylamys elegans venusta (Thomas, 1902).

Other hosts: Monodelphis domestica (Wagner, 1842).

Site of infection: Attached to mucosa in first $70 \mathrm{~mm}$ of length of small intestine (total length of small intestine $111 \mathrm{~mm}$ ).

Type locality: Porvenir, $675 \mathrm{~m}$, Department of Chuquisaca, Bolivia, South America $\left(20^{\circ} 45^{\prime} \mathrm{S}, 63^{\circ} 13^{\prime} \mathrm{W}\right)$.

Specimens deposited: Holotype: USNM Helm. Coll. no. 82216 from $T$. elegans venusta, American Museum of Natural History (AMNH), Department of Mammalogy Catalogue no. 261257 (Museum of South-

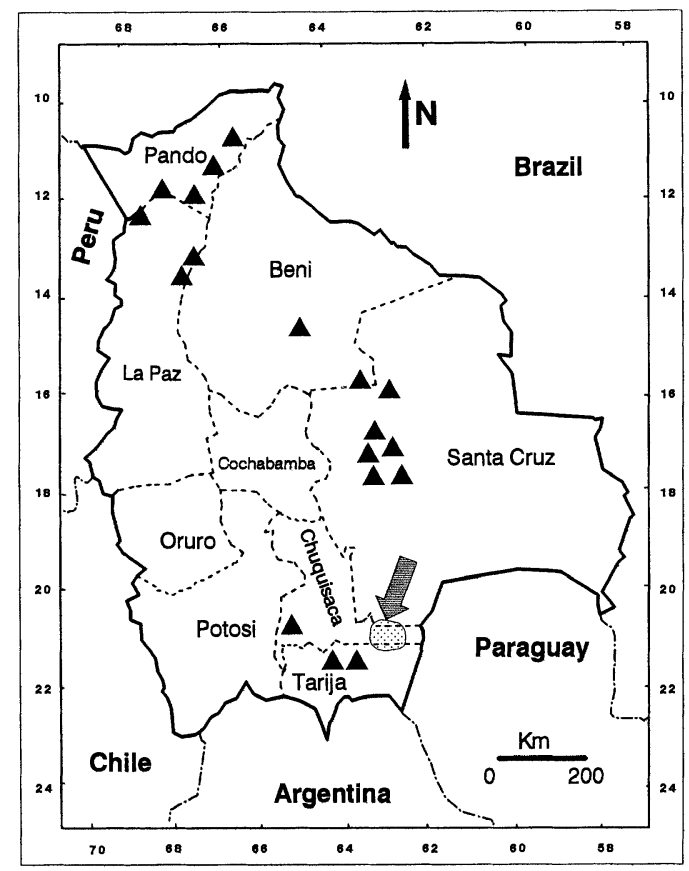

FIGURE 6. Map of Bolivia showing generalized collection localities of marsupials from throughout Bolivia (1984-1987). Triangles show collections of marsupials from which cestodes were not found; shaded zone, indicated by the arrow, shows area from which marsupials infected with Linstowia cestodes were found.

western Biology [MSB] Frozen Tissue Collection no. NK12554), collected on 6 July 1985. Paratypes: Two individuals, University of California Davis Nematode Collection (UCDNC) no. UCDNC 2831 and UCDNC 2832 from $M$. domestica, AMNH, Department of Mammalogy Catalogue no. 261244 (MSB Frozen Tissue Collection no. NK12669), collected on 15 July 1985.

Etymology: This cestode is named after the late Gerald D. Schmidt, friend, teacher, parasitologist.

\section{Remarks}

With the exception of Didelphis virginia Kerr, which is a recent immigrant to the Nearctic Region, marsupials of the family Didelphidae presently occur only in the neotropics (Simpson, 1980; Marshall, 1982). Marsupials representing Didelphidae (which includes species of the genera Thylamys and Monodelphis) are known as fossils extending back as far as 65 million years in South America with a somewhat older history in North America (Marshall, 1982, 1988; Reig et al., 1987). The ancestry of Australian marsupials currently is under debate (Reig et al., 1987), and although there is some evidence that the Australian marsupials were derived from micribiotheriid ancestors (Reig et al., 1987), these debates have not been resolved. At the present time didelphid marsupials (the hosts of Linstowia in the neotropics) do not occur in Australia or New Guinea (Simpson, 1980; Reig et al., 1987); therefore, L. schmidti is compared only with Linstowia ihe- 
ringi, presently the only species of the genus Linstowia known from mammals in the neotropics.

These cestodes do not resemble any previously described from marsupials in the neotropics. Linstowia schmidti $\mathrm{n}$. sp. can be recognized as distinct from $L$. iheringi in having a much smaller strobila (mean length of $9.6 \mathrm{~mm}$ for $L$. schmidti vs. about $46 \mathrm{~mm}$ for $L$. iheringi) and fewer proglottids (24-38 vs. about $84-$ 200 in $L$. iheringi). In addition, the terminal gravid proglottids of $L$. schmidti are much longer than wide, which is a sharp contrast to the wide and short terminal gravid proglottids in $L$. iheringi. However, an increase in relative length of gravid proglottids occurs in both species. In $L$. schmidti, the eggs are distributed relatively evenly throughout the parenchyma of the terminal gravid proglottids, whereas in $L$. iheringi the eggs are distributed primarily in the lateral margins of the gravid proglottids.

A clarification of the correct specific name of $L$. iheringi is necessary as many authors are using jheringi instead of iheringi. The cestode was named by Zschokke (1904a) after H. von Ihering. However, it appears that the name was mistyped in the paper by Zschokke (1904a), where on page 51 he states "... ; mich selbst setzt das freundliche und sehr verdankenswerte $\mathrm{Zu}$ vorkommen H. v. Jherings in Sao Paolo in den Stand, einen Cestoden aus Peramys americana zu beschreiben." In another paper written later, Zschokke (1904b) used the correct spelling of $\mathrm{H}$. von Ihering and used the correctly spelled specific name where he states, " $\mathrm{H}$. $v$. Ihering übergab mir in sehr verdankenswerter Weise einen Cestoden aus Peramys americana, den ich an andrer Stelle beschreiben werde," and "... ; Peramys americana beherbergt Linstowia iheringi Zsch.; in Didelphys bistriata wohnt $L$. brasiliensis Janicki." We consider the second paper by Zschokke (1904b) to represent a "justified emendation." This explicitly follows the International Code of Zoological Nomenclature (Ride et al., 1985), article 33b, i and ii (p. 73) and example therein.

\section{DISCUSSION}

Although collections of marsupials were made from throughout Bolivia, individuals infected with Linstowia cestodes were recorded only from the region of Porvenir in southeastern Bolivia (Fig. 6). In this area, the life cycle of cestodes parasitic in small opossums of the genera Thylamys and Monodelphis still is intact; the intermediate host(s), unknown in this case, must occur in intimate association with the definitive host. These tapeworms have been reported also from Brazil (Zschokke, 1904a, 1904b; Janicki, 1906; Gomes, 1979); however, no information is available on the ecological associations of $L$. iheringi and its marsupial hosts in this region. Because of the apparent age of this host-parasite association (a trans-Antarctic land mass connection between South America and Australia is thought to have persisted only into the early Eocene [see review by Raven and Axelrod, 1974]), we propose that current species of Linstowia in the neotropics represent ecological-historical relicts. Furthermore, the area in southeastern Bolivia may represent an ecologically old region where the life cycle of Linstowia currently is being maintained, perhaps due to the presence of suitable intermediate hosts. This idea is supported by the absence of Linstowia from other regions of Bolivia, despite extensive collections of marsupials (including Thylamys and Monodelphis) from other areas, and by the work of Sarmiento (1976), who provided evidence that the Chaco habitat-type may represent one of the oldest biotic associations in the neotropics, second in age only to the rain forests.

The paucity of information concerning the distribution and general ecological associations of linstowiid cestodes and their hosts in other areas of South America hampers efforts to understand biogeographic patterns in this genus. The recognition of $L$. schmidti from Bolivian marsupials, nearly a century after the original description of $L$. iheringi, is a further indication of how little is known of the helminth fauna of mammals in the neotropics.

\section{ACKNOWLEDGMENTS}

We thank S. Anderson, T. Yates, J. Cook, and J. Ubelaker for assistance with collection and identification of cestodes. This work was partly funded by NSF grants BSR-9024816 and BSR8612329; the Latin American Institute; and the Tinker Foundation, The University of New Mexico. Thanks also are extended to Otto Carlos Jordán Camacho of the Zoo Santa Cruz, Fauna Sudamericana, for technical assistance in Bolivia.

\section{LITERATURE CITED}

BAER, J. G. 1927. Monographie de la famille Anoplocephalidae. Bulletin Biologique de la France et al Belgique, Supplément 10: 1-24.

BEVERIDGE, I. 1983. The genus Linstowia Zschokke, 1899 (Cestoda: Anoplocephalidae) in Australian mammals with the description of a new species, L. macrouri. Systematic Parasitology 5: 291-304.

GoMES, D. C. 1979. Contribuicao ao conhecimento dos helmintos parasitos de marsupiasis no Brasil, da colecao helmintologica do Instituto Oswaldo Cruz. (Cestoda, Archiacanthocephala e Linguatulida). Revista Ibérica de Parasitologia 39: 587599.

JANICKI, C. vON. 1906. Studien an Säugetiercestoden. Zeitschrift für Wissenschaftliche Zoologie 81: 505597.

Marshall, L. G. 1982. Evolution of the South American Marsupialia. In Mammalian biology in South America, M. A. Mares and H. H. Genoways (eds.). 
The Pymatuning Symposia in Ecology, Special Publication Series of the Pymatuning Laboratory of Ecology 6: 251-272.

1988. Land mammals and the great American interchange. American Scientist 76: 380-388.

Raven, P. H., AND D. I. AXelrod. 1974. Angiosperm biogeography and past continental movements. Annals of the Missouri Botanical Garden 61: 539673.

Reig, O. A., J. A. W. Kirsch, and L. G. Marshall. 1987. Systematic relationships of the living and neocenozoic American "opposum-like" marsupials (suborder Didelphimorphia), with comments on the classification of these and of the cretaceous and paleogene New World and European metatherians. In Possums and opossums: Studies in evolution, Vol. 1, M. Archer (ed.). Surrey Beatty and Sons, Pty Ltd., New South Wales, p. 1-89.

Ride, W. D. L., C. W. SABRosky, G. Bernardi, AND R. V. Melville (eds.). 1985. International code of zoological nomenclature, 3rd ed. University of California Press, Berkeley and Los Angeles, $338 \mathrm{p}$.
SARmiento, G. 1976. Evolution of arid vegetation in tropical America. In Evolution of desert biotas, D. W. Goodall (ed.). University of Texas Press, Austin, p. 65-99.

SChMid, G. D. 1986. Handbook of tapeworm identification. CRC Press, Boca Raton, Florida, $675 \mathrm{p}$.

Simpson, G. G. 1980. Splendid isolation, the curious history of South American mammals. Yale University Press, New Haven, 266 p.

UnZUETA, O. Q. 1975. Mapa ecologico de Bolivia. Minesterio de Asuntos campesinos y Agropecuarios, La Paz, Bolivia, 432 p.

ZsCHOKKE, F. 1899. Neue Studien an Cestoden aplacentaler Säugethiere. Zeitschrift für Wissenschaftliche Zoologie 65: 404-445.

- 1904a. Die Darmcestoden der amerikanischen Beuteltiere. Centralblatt für Bakteriologie, $\mathrm{Pa}$ rasitenkunde und Infektionskrankheiten, 1st Abt. 36: 51-62.

. 1904b. 2. Die Cestoden der südamerikanischen Beuteltiere. Zoologischer Anzeiger 27: 290293. 